Available online at: https://journals.researchsynergypress.com/index.php/ijtaese

International Journal of Theory and Application in Elementary and Secondary School Education

(IJTAESE)

ISSN 2684-7167 (online)

Volume 3 Number 1 (2021): 01-14

\title{
Indonesian Secondary School Students' Happiness at the Beginning of Covid-19 Pandemic
}

\author{
Heny Solekhah \\ Sabilurrasyad Islamic Boarding School
}

\begin{abstract}
Happiness is a subjective assessment of individual wellbeing. Adolescents, especially secondary school students living in Islamic Boarding School, experience dramatic changes from learning at their dormitory with face-to-face teaching method to distance learning at home with minimum activities outside their houses. The survey was conducted on 111 respondents of students who had to return home due to the outbreaks of covid-19 pandemic for two months. The research found that the dramatic changes made them had difficulty to adapt new activities at home for a long time while studying independently through distance learning. Only a third of the sample felt happy during the online learning while the majority felt negative emotions such as boredom, unhappiness, and loneliness. The adolescents' life satisfaction and community engagement significantly correlated with happiness although the size effects were medium. Female students also had lower happiness variables than males. To maintain their happiness, during the pandemic, most of them prefer activities that mostly trigger a sedentary lifestyle.
\end{abstract}

Keywords: Happiness; Covid-19; Secondary School Students; Indonesia; Islamic Boarding School.

This is an open access article under the CC-BY-NC license.

\section{INTRODUCTION}

Coronavirus disease (Covid-19) is a new virus that spreads around the globe since its appearance in Wuhan in December 2019. Due to its fast-moving outbreaks among countries, WHO has stated that Coronavirus is a pandemic (Wind, Rijkeboer, Andersson, \& Riper, 2020).

Responding to the pandemic, every country around the globe set the priority of how to prevent the transmission, to protect vulnerable such as children and comorbid people, and to reset the safest methods of working, industry, and education (Flood, MacDonnell, Philpott, Thériault, \& Venkatapuram, 2020). A new social behavioral or new normal including social/physical distancing, general hygiene such as handwashing, masking, massive testing, and the tracing is massively encouraged by the government officials (Gao, Zheng, Yingnan, Chen, Mao, Chen, Wang, Fu, \& Dai 2020; Hall, Laddu, Phillips, Lavie, \& Arena, 2020).

During COVID-19 Pandemic period, there are several new behaviors must be kept in order to be safe. One of them in the education field, 68 million students in Indonesia should study at home; around 6 million of them are pre-primary school students (UNESCO, 2020c).

Indonesian Minister of Education, Nadiem Makarim urge schools to adopt online learning in lieu of face-to-face learning, and it must be taught based on the students' interests focusing on life-skills. However, the migration from conventional teaching to online mode does not run smoothly. 
The school closures could bring adverse impacts on society, such as interrupted learning experiences, unprepared distance and homeschooling by parents, limited access to the internet for students in rural areas or disadvantaged families, nutrition problems, limited childcare due to busy parents, and the tendency of dropout rates (UNESCO, 2020a). During the school closures, digital learning could both widening and narrowing learning inequalities among the students (Moreno \& Gortazar, 2020). According to Kemp (2020), internet users in Indonesia reach 175 million people in January 2020, and only $46 \%$ of Indonesian children have access to the internet (Jacobs Foundation, 2020).

In Indonesian Islamic boarding schools or pesantren, the school closures have caused dramatic changes. Since the announcement from the Indonesian Minister of Education in March, many Islamic boarding schools are closed because due to the fear of Covid-19 spread. The students were sent home (Mediana, 2020; Santoso, 2020; Tari, 2020). In some other Islamic boarding schools /pesantren, their students should do physical distancing because one of them was positively infected by this virus (BBC Indonesia, 2020). Hence, the reopening of Islamic boarding schools needs careful decisions (Sidik, 2020).

Before the pandemic appears, Indonesian children age are considered to have a positive sense of wellbeing with an average score of 7.8, equal to Taiwan and Bangladesh (Jacobs Foundation, 2020). For Indonesian children, life as a student is the most positive aspect, while the home was the least positive (Jacobs Foundation, 2020). Besides, the young Indonesian generation between 15 and 19 years old is the happiest in the world (Varkey Foundation, 2017). However, For the students, being socially isolated from peers could lead to a decrease in mental health and wellbeing. The school closures and social distancing could increase loneliness (Loades et al., 2020). Therefore, it is important to know whether Indonesian students, especially those who study in Islamic boarding school, are happy during the online learning, how they feel at home, and how they maintain their happiness.

\section{LITERATURE REVIEW}

Happiness is subjective wellbeing that is closely related to life satisfaction. An individual subjectively judges and evaluates his or her own life whether he or she is happy (Eryilmaz, 2012; Lewis, Huebner, Malone, \& Valois, 2011; Lynch, 2015). It means that the more an individual feels satisfied, the more likely he or she obtains happiness. Although happiness means different across individuals, culture plays an important role in defining what happiness is for adolescents (Kapoor, Rahman, \& Kaur, 2018).

The children's emotional, social, and cognitive development is also influenced by their social bonding (Eryilmaz, 2012). Playing games and doing homework together, for example, are necessary activities in order to get both pleasure and satisfaction (Saldarriaga, Bukowski, \& Greco, 2015). Solidarity with peers could increase a child's power temporarily in a difficult situation (Cornell \& Limber, 2015; Greco, Holmes, \& McKenzie, 2015). Indeed, the childrens' socio-emotional development is positively influenced by friendships (Garrote, Sermier Dessemontet, \& Moser Opitz, 2017).

Life events are correlated with subjective wellbeing (Wootton, Davis, Mottershaw, Wang, \& Haworth, 2017). The peers' collaboration and solidarity could increase a child's power temporarily in a difficult situation (Cornell \& Limber, 2015; Greco et al., 2015). Indeed, the children's socio-emotional development is positively influenced by friendships (Garrote et al., 2017).

During the social confinement, the Indonesian government concerns greatly on the prevention of the spread on children. However, the psychological impact of this policy on children and adolescents should not be neglected. There is a possibility that the students have stressors such as boredom, confusion, anger, the lack of contact with their friends, classmates, and teachers, and other problems (Brooks et al., 2020; Wang, Zhang, Zhao, Zhang, \& Jiang, 2020). 
Several online surveys have been conducted in response to the influence of the pandemic on children and adolescents. The current research found that the mental health of children and adolescents was influenced by the Covid-19, especially the prevalence of the anxiety and the depression (Wagner, 2020). The survey conducted by Orgilés, Morales, Delveccio, Mazzeschi, and Espada (2020) found that 1,143 Italian and Spanish parents addressed the changes in their children's and adolescents' emotional states in which more than half of them experienced boredom and difficulty and concentrating. Another research conducted in Bangladesh also found that Covid-19 had negative impacts on children in which they were suffering from a sleeping disorder, depression, and anxiety (Yeasmin, Banik, Hossain, Hossain, Mahumud, Salma, \& Hossain, 2020). Chinese adolescents surveyed by (Zhou, Zhang, Wang, Guo, Wang, Chen, Liu, Chen, \& Chen, 2020) also suffered from the symptoms of depression and anxiety. (Duan, Shao, Wang, Huang, Miao, Yang, \& Zhu, 2020) also found similar symptoms in Chinese adolescents, accompanied by the addiction of smartphone and internet. These researches are more focusing on the negative emotional states. However, the research about the subjective wellbeing has not been found in the literature. Therefore, it is important to investigate whether the adolescents experience happiness during the pandemic by conducting online surveys.

\section{Research Questions}

Happiness and life satisfaction were correlated negatively to the risk of depression (Seo, Kim, Kim, Kim, Park, \& Yoon, 2018). The depression due to negative thoughts could be decreased when individuals have positive cognitions and emotions (Lightsey, 1994). In the contrary, the dissatisfaction could predict depression (Koivumaa-Honkanen, Kaprio, Honkanen, Viinamäki, \& Koskenvuo, 2004). Happy people also are more compassionate to contribute to society (Burns, 2016). In other words, the happier person, the more likely he or she would make a contribution to the surrounding. Since happiness is important for adolescents during the pandemic, some research questions are proposed:

1. Is there any correlation between the happiness variables (the state of being happy, life satisfaction, and community engagement)?

2. Is there any significant difference between males and females in their happiness during the early pandemic?

3. How do the students feel during the study at home, and how do they maintain their happiness?

\section{RESEARCH METHOD}

This research was conducted by online surveying the adolescent students who studied in pesantren or an Islamic Boarding School in Kendal, Jawa Tengah. According to the statistic of the Ministry of Religious Affairs, there are 119 pesantren in Kendal (Agama, 2019). Kendal was chosen because it is located nearby the capital of Jawa Tengah. One modern pesantren was chosen because it had wide ranges of male and female adolescent age groups with 330 students in total, and the institution agreed to take the survey voluntarily.

The respondents were the students in Islamic boarding school in Kendal, Jawa Tengah. The data was taken in early May 2020, two months after the school closure. The data was collected through Google Form. The questionnaire used is the Indonesian Short Mental Health Continuum (Indonesian MHC-SF) developed by Keyes (2006), which consists of fourteen items with a Likert type scale ranging from 1 "never" to 6 "every day". The reliability test is high with Cronbach Alpha .80. In addition, two questions were also asked in which the students explained in short essays about their happiness at home. 
This instrument is generally used to measure the happiness level of adolescents in a normal situation. During the pandemic, adolescents' experiences are different from normal situations. Therefore, two questions in the form of an essay were also asked.

The questions were "How do you feel during the pandemic?" and "What do you do to maintain your happiness during the school closure?"

The respondents were 111 students (70 females and 41 males) who study in an Islamic boarding school or a third of the overall number of the students. A half of the respondents (54.1\%) were grade VII, $30.6 \%$ of them were grade VIII, $1 \%$ from grade IX, grade X and XI were $3.6 \%$ and $10.8 \%$, respectively (see table 1).

Table 1 Composition of Study Participants

\begin{tabular}{llllll}
\hline & Male & Female & Total & Age \\
\hline Grade 7 & number & 25 & 35 & & Average: 12.6 \\
& percent & 41,7 & 58,3 & 60 & Stand Dev:0.50 \\
\hline \multirow{2}{*}{ Grade 8 } & number & 12 & 22 & & Average: 13.7 \\
& percent & 35,3 & 64,7 & 34 & Stand Dev:0.54 \\
\hline \multirow{2}{*}{ Grade 9 } & number & 1 & 0 & & Average: 15 \\
& percent & 100 & 0 & 1 & Stand Dev:0 \\
\hline \multirow{2}{*}{ Grade 10 } & number & 0 & 4 & & Average: 15.7 \\
& percent & 0 & 100 & 4 & Stan Dev: 0.4 \\
\hline \multirow{2}{*}{ Grade 11 } & number & 3 & 9 & & Average: 16.8 \\
& percent & 25 & 75 & 12 & Stand Dev: 0.55 \\
\hline
\end{tabular}

111

\section{FINDINGS AND DISCUSSION}

Based on table 2 below, it could be seen the responses of the students related to their happiness while studying at home. Only two items are showing that the students.

Among fourteen statements, only two items had a mean score of more than five, meaning "almost every day". They are the interest and the satisfaction with life. Most of the responses were four, meaning "2 to 3 times a week", while the contribution to the society was three or once a week. 
Table 2. The Students' Responses

\begin{tabular}{|l|l|l|l|}
\hline & Item & Mean & $\begin{array}{l}\text { Stand } \\
\text { Dev }\end{array}$ \\
\hline 1 & Happy & 4.95 & 1.16 \\
\hline 2 & Interested in life & 5.24 & 1.08 \\
\hline 3 & Satisfied with life & 5.15 & 1.36 \\
\hline 4 & That you have something important to contribute to society & 3.25 & 1.69 \\
\hline 5 & That you belonged to a community & 4.01 & 1.86 \\
\hline $\begin{array}{l}\text { That our society is a good place or is becoming a better place, for all } \\
\text { people }\end{array}$ & 4.55 & 1.55 \\
\hline 7 & Those people are basically good & 4.84 & 1.41 \\
\hline 8 & That the way our society works made sense to you & 4.61 & 1.45 \\
\hline 9 & That you liked most part of your personality & 4.83 & 1.20 \\
\hline 1 & $\begin{array}{l}\text { That you are good at managing the responsibilities of your daily life } \\
0\end{array}$ & 4.26 & 1.48 \\
\hline $\begin{array}{l}1 \\
1\end{array}$ & That you have warm and trusting relationships with others & 4.58 & 1.46 \\
\hline 1 & $\begin{array}{l}\text { That you had experiences that challenged you to grow and become a } \\
\text { better person }\end{array}$ & 4.74 & 1.37 \\
\hline $\begin{array}{l}1 \\
3\end{array}$ & Confident to think or express your own ideas and opinions & 4.05 & 1.59 \\
\hline $\begin{array}{l}1 \\
4\end{array}$ & That your life has a sense of direction or meaning of it & 4.49 & 1.52 \\
\hline
\end{tabular}

\section{Correlation among Variables}

Since the data is negatively skewed, Spearman's correlation coefficient (rs) with one-tailed analysis (Cohen, 1988). Among all variables, the inferential statistical analysis shows the only correlation between "I am happy" and "I am interested in life", Spearman's correlation coefficient rs $=.38, \mathrm{p}<.01,1$-tailed. The effect size was medium, meaning that the satisfaction with life was a medium predictor of happiness. However, significant correlations between happiness and other 12 variables were not found.

The variables that had strong correlation were "That your life has a sense of direction and meaning of it" and other variables, such as "Confident to think or express your own ideas and opinions" with Spearman's correlation coefficient $\mathrm{rs}=.59, \mathrm{p}<.01$, 1-tailed; "That you liked most part of your personality" with Spearman's correlation coefficient $r s=.56, \mathrm{p}<.01$, 1-tailed; "That you belonged to a community" with Spearman's correlation coefficient trs $=.59, \mathrm{p}<.01,1$-tailed; and "That you had experiences that challenged you to grow and become a better person" with $\mathrm{rs}=.53$, $\mathrm{p}<.01,1$-tailed.

While there was a strong correlation between "That you belonged to a community" and "That our society is a good place, or is becoming a better place, for all people" with $r s=.46, \mathrm{p}<.01,1$-tailed, the interest in life was a medium predictor of life satisfaction with $r s=.32, p<.01,1$-tailed. The contribution of adolescents to the society was also a medium predictor of their feeling of belonging to the community with $\mathrm{rs}=.30, \mathrm{p}<.01,1$-tailed. 


\section{Male and Female Students' Happiness Variables}

Overall, there was no significant difference between male and female on their happiness. However, statistical analysis found that there were differences between male and female students believing that people are basically good (Mdn: 5, Mann-Whitney $(\mathrm{U})=963.5, \mathrm{z}(110)=-2.05, \mathrm{p}<.05, \mathrm{r}=-0.20,2$-tailed; the way the society works made sense to them.(Mdn: 5, Mann-Whitney $(U)=828.5, z(110)=-3.87, p<.05$, $r=-0.36$, 2-tailed.; they like most of their personality (Mdn: 5, Mann-Whitney $(U)=1066, z(110)=-2.28$, $\mathrm{p}<.05, \mathrm{r}=-0.22,2$-tailed; that they have warm and trusting relationship with others (Mdn: 5, MannWhitney $(\mathrm{U})=989, \mathrm{z}(110)=-2.83, \mathrm{p}<.05, \mathrm{r}=-0.36,2$-tailed; and the capability of the managing responsibilities or daily activities (Mdn: 5, Mann-Whitney $(U)=978, z(110)=-2.87, p<.05, r=-0.27,2-$ tailed.

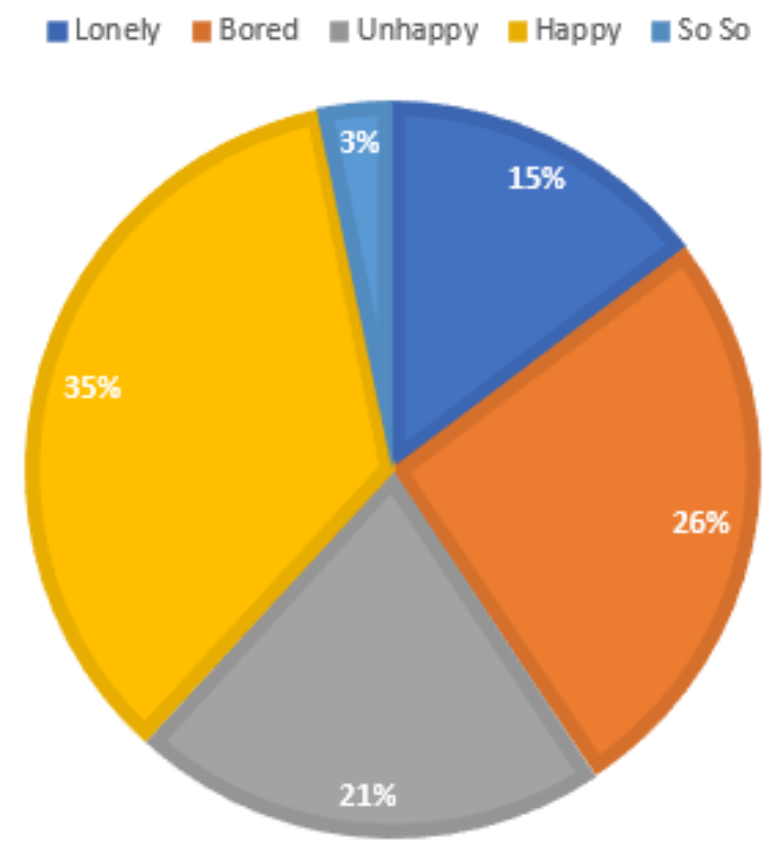

Figure 1. The Student's Feeling During the Distance Learning

\section{The Students Feeling at Home Confinement and the Activities to Maintain Happiness}

Figure 1 and figure 2 were collected from the short essays written by the students in the survey. The responses were then calculated and grouped. Based on figure 1, it shows that although the state of being happy appeared, in total, the negative feelings (loneliness, boredom, and unhappiness) outweighed the positive feelings. The unchanging emotion (so so) was the lowest.

The students explained the reasons for the negative feelings were due to the absence of physical interaction between them, the learning difficulties especially, to adapt the online learning as well as to understand the learning materials (common school subjects and Islamic subjects), and the limited internet data that hindered their access to learning activities and entertainment.

The duty to follow the health protocol also limited their opportunity to do outdoor activities and made them spend more time at home. Figure 2 illustrates the ways the students maintained their happiness when they were confined at home for two months since the school closures. Overall, nonphysical activities were high (Smartphone use, TV watching, and games). Family time, helping the family 
at home, and friends' interaction were also done by the students to maintain their happiness. However, entertainment and hobbies were not specifically mentioned by the students. Physical exercise, however, was not frequently mentioned by them.

\section{Happiness and Distance Learning in the Pandemic}

In adolescents, the changes in psychological, emotional, and social aspects of their lives are complex and might influence their level of wellbeing (Steinberg, 2005). The dramatic change in their bodies, hormones, and the transition of new responsibilities are experienced by them.

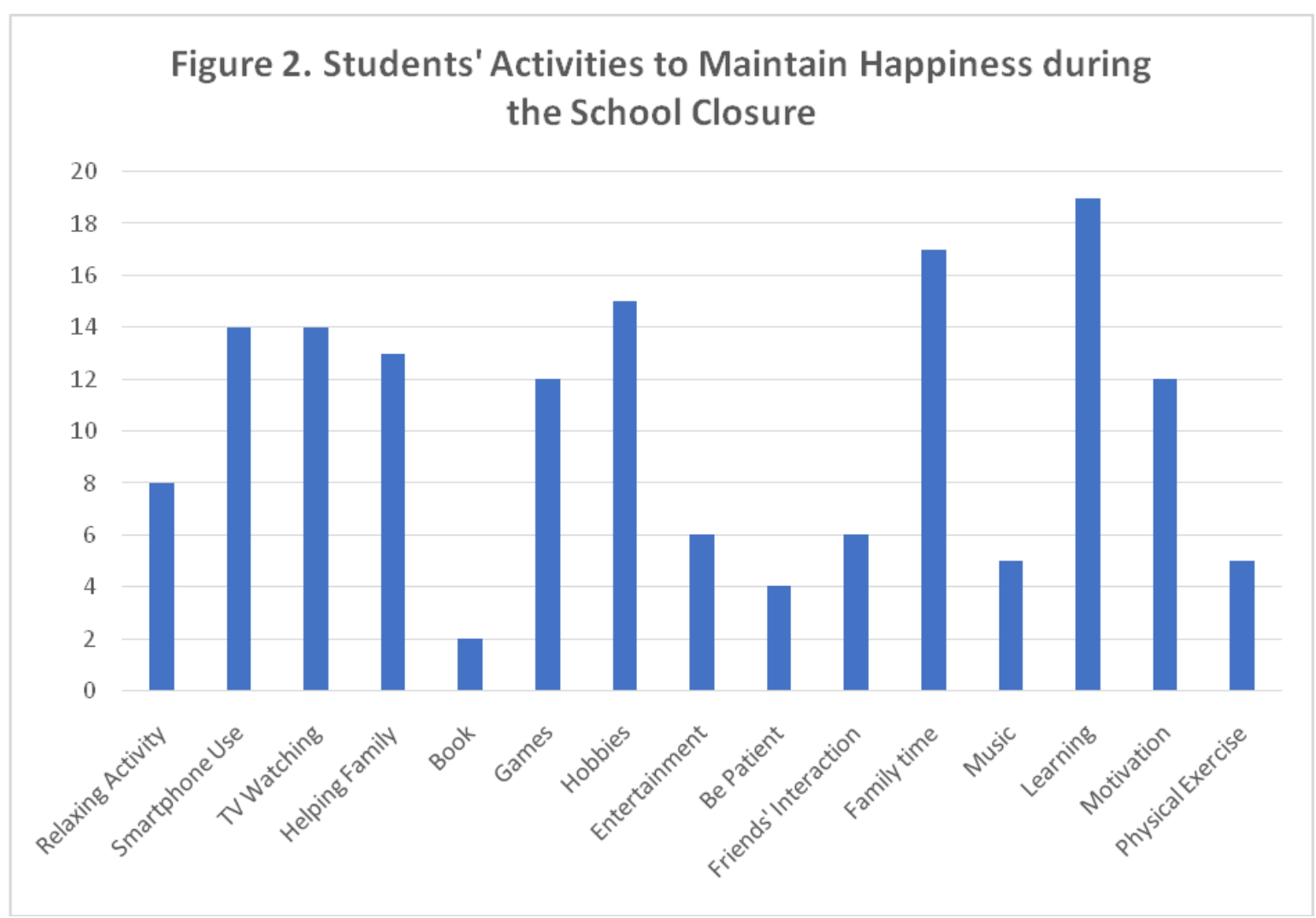

Figure 2. Student's Activities to Maintain Happiness during the School Closure

Generally, female adolescents experience more obvious psychological changes and more likely to have internal stressors and internalize problems compared to males (Flook, 2011). The reasons are the social interaction among females is more complex than males. Society's expectation of body images and the responsibilities in doing household could also influence the level of stressors for girls (Flook, 2011).

Compared to the happiness in the normal life, adolescents' happiness in a new normal was lower. Being locked down, the inability to do the school routine, the decreased physical contact with others causes frustration, boredom, and the feeling of being isolated (Brooks et al., 2020). The students who previously spent 24 hours per day with their friends and did various activities now should stay at home with an irregular schedule. Although many sectors are gradually reopened, school closures could be longer.

Another factor that influences happiness is wealth (Whiteley, Clarke, \& Stewart, 2020). Compared to traditional learning, the learners in distance learning need inner motivation and self-discipline, supported by appropriate technology and literacy skills (Donohue et al., 2020). However, distance learning 
opens a wider gap between the families who could afford gadgets and internet data and the families who struggled to survive due to the loss of employment.

\section{CONCLUSION}

Based on the research, it could be found that at the beginning of the pandemic, there were statistically significant correlations among the adolescents' happiness variables with medium effect size. However, there were no significant differences between male and female students. Although the students stated that they were happy, negative feelings such as boredom and loneliness were present.

The pandemic has a great impact on adolescents, especially on their happiness. It does not only decrease their positive wellbeing but also their access to a higher quality of learning. The activities are done to cope with the boredom, loneliness, and other negative feelings that tend to make them less active physically. It needs more support from the government and parents in order to avoid the prolonged negative consequences of home confinement.

Implementing distance learning for young learners is challenging compared to the older group of students (Dale, 2020). The migration takes time not only for the students but also for the teachers. Giannini (2020) suggests that the technological barriers should be tackled by providing alternatives of distance learning such as radio or television, ensuring the children consume healthy meals, and providing individual learning supervision for diverse learners. The creativity of the teachers and the zero-rate-policy by telecommunication providers could facilitate learning better; cash transfer could help the families in feeding the children; and the role of parents and school are also important in maintaining the peer interactions and social relationships (Saveedra, 2020).

Further, UNESCO (2020d) provides the links that can be accessed to support distance learning, such as the psychosocial support by UNICEF, the systems of digital learning management, learning platforms on mobile devices, offline learning applications, online course platforms, and other websites of selfdirected learning. UNESCO (2020b) also recommends that in using digital learning modalities, the teachers should consider the availability of electricity, internet connection, the psychosocial conditions of the learners, and the socioeconomic background of the families. Thus, the Covid-19 pandemic would change the educators on how to teach students as globalized people with the life skills needed by redefining the teachers as the facilitators in both traditional and digital learning (Luthra \& Mackenzie, 2020).In addition, the teachers in distance learning need to build a sense of community, the adaptability of using multimedia contents and making the students familiar with the online learning environment.

Indonesian ministry of education mandates Televisi Republik Indonesia (TVRI), an Indonesian national broadcasting channel that provides educational videos for students ranging from pre-school to high school on weekdays. This approach is aimed to reach more students in a wider area, although its contents are limited. Recently, the government announces the subsidy of internet data for the students (Kebudayaan, 2020). However, it takes time to implement this policy in all schools in Indonesia due to the procedure of Biaya Operasional Sekolah (school's operational funding).

\section{Family Support for Adolescents Mental Health and Wellbeing Home}

The commitment to religion, strong bond with parents and friends plays an important role in the Indonesian young generation's happiness (Varkey Foundation, 2017). Both maternal and paternal are important for positive adolescent development (Yap \& Baharudin, 2016). During the pandemic, parents are encouraged to keep their children healthy and happy at home (Mathers, 2020). Parents have important roles in educating their children, especially during the long intermittent of school. They must understand 
the characteristics of their children and should not force their children to study by screaming or beating them (Rohmah, 2020). The parents should show empathy to the students because migrating from normal to online learning is uneasy (Smoyer, O’Brien, \& Rodriguez-Keyes, 2020).

Apart from the mental health issue, sedentary behavior is getting more common among society compared to a few decades ago, in which people have less physical activity. This phenomenon is considered a 'sedentarism pandemic' (Hall et al., 2020). Further, Thompson, Rodebaugh, Bessaha, and Sabbath (2020) also found that the more often parents and adolescents are isolated, the more likely they have a negative health lifestyle. Moreover, the policy on people confinement increases the risk of physical and mental health conditions (Ricci et al., 2020).

The restriction during the pandemic creates psychosocial suffering, and it has an association with a negative healthy lifestyle, poor quality of sleep, physical inactivity, unhealthy dietary habits, unemployment, and limited social contact. On the other hand, the use of technology increases greatly (Ammar et al., 2020; Brazendale et al., 2017; Xiang, Zhang, \& Kuwahara, 2020). Being physically less active, exposed to longer screen time, poor sleep patterns, and unhealthy diets could increase weight and decrease the cardiorespiratory fitness system (Wang et al., 2020). Children between 5 and 17 years old are recommended to do moderate-vigorous physical activity, including muscle strength training for a minimum of 60 minutes per day at least three times a week (Bates et al., 2020; Margaritis et al., 2020).

Children and adolescents need physical exercise and play in their developmental periods. Therefore, the school closures and the confinement disrupt their development, and these problems could have negative consequences on mental health, sedentary activity (Mittal, Firth, \& Kimhy, 2020), and sleep quality (Bates et al., 2020). Although the prolonged impact of Covid-19 on physical inactivity has not been investigated, research conducted by Okazaki, Suzuki, Sakamoto, and Sasaki (2015) found that the children and adolescents in East Japan who survived the earthquake and tsunami had decreased physical inactivity for three years.

It is required good parenting skills for children when they are locked-down at home. The parents should provide not only food, shelter, and learning assistance, but also examples of self-discipline to maintain mental health and wellbeing for their children (Wang et al., 2020).

\section{LIMITATION \& FURTHER RESEARCH}

The study was conducted with a low population, and therefore, the findings could not be generalized. Due to the limited access to reach the respondents, it needs more support from other parties in order to have more participating students. The existing study also found that the effect sizes of the happiness variables were medium. It is suggested that future studies should explore the reasons why the students felt less frequent positive feelings during the pandemic.

As sedentary lifestyle becomes more common among the adolescent, it is suggested that the further research should investigate the sedentary lifestyle of the students during the pandemic in order to find how far the effect of lockdown to their healthy behavior and their level of fitness.

\section{REFERENCES}

Agama, K. (2019). Statistik Data Pondok Pesantren. Retrieved from https://ditpdpontren.kemenag.go.id/pdpp/statistik?id=33

Ammar, A., Trabelsi, K., Brach, M., Chtourou, H., Boukhris, O., Masmoudi, L., ... Hoekelmann, A. (2020). Effects of home confinement on mental health and lifestyle behaviours during the COVID-19 
outbreak: Insight from the ECLB-COVID19 multicenter study. Biology of Sport. Retrieved from http://dx.doi.org/10.5114/biolsport.2020.96857. doi:10.5114/biolsport.2020.96857

Bates, L. C., Hanson, E. D., Zie, G., Stanford, K., Moore, J. B., Kerr, Z. Y., ... E. Kline, C. (2020). COVID-19 impact on behaviors across the 24-hour day in children and adolescents: Physical activity, sedentary behavior, and sleep. Children, 7. doi:10.3390/children7090138

Burns, G. (2016). Being: Building Human Capital to Benefit Individuals and Society. Retrieved from https://thesolutionsjournal.com/2016/02/22/happiness-and-psychological-well-being-buildinghuman-capital-to-benefit-individuals-and-society/

Brazendale, K., Beets, M. W., Weaver, R. G., Pate, R. R., Turner-McGrievy, G. M., Kaczynski, A. T., . . . Hippel, P. T. v. (2017). Understanding differences between summer vs. school obesogenic behaviors of children: the structured days hypothesis. International Journal of Behavioral Nutrition and Physical Activity, 14:100, 1-14. doi:10.1186/s12966-017-0555-2

Brooks, S. K., Webster, R. K., Smith, L. E., Woodland, L., Wessely, S., Greenberg, N., \& James Rubin, G. (2020). The psychological impact of quarantine and how to reduce it: rapid review of the evidence. www.thelancet,com, 395, 912-920.

Cohen, J. (1988). Statistical Power Analysis for the Behavioral Sciences (2nd ed.). Hillsdale, New Jersey: Lawrence Erlbaum Associates.

Cornell, D., \& Limber, S. P. (2015). Law and Policy on the Concept of Bullying at School. American Psychological Association, 70(4), 333-343. doi:10.1037/a0038558

Dale, M. (2020, 2 April 2020). 'A New Industry Overnight': Early Education In A Distance Learning World Retrieved from https://laist.com/2020/04/02/coronavirus_early_education_los_angeles_distance_learning.php

Donohue, C., Johnson, A., Lucas, P., Lynd, C., Mukerjee, J., \& Thouvenelle, S. (2020, 16 March 2020). Distance Learning and Early Childhood Education. Retrieved from https://eclkc.ohs.acf.hhs.gov/professional-development/article/distance-learning-early-childhoodeducation

Duan, L., Shao, X., Wang, Y., Huang, Y., Miao, J., Yang, X., \& Zhu, G. (2020). An investigation of mental health status of children and adolescents in china during the outbreak of COVID-19. Journal of affective disorders, 275, 112-118. Retrieved from https://pubmed.ncbi.nlm.nih.gov/32658812 and https://www.ncbi.nlm.nih.gov/pmc/articles/PMC7329661/. doi:10.1016/j.jad.2020.06.029

Eryilmaz, A. (2012). A model for subjective wellbeing in adolescence: Need satisfaction and reasons for living. Social Indicators Research, 107(3), 561-574. Retrieved from https://doi.org/10.1007/s11205011-9863-0. doi:10.1007/s11205-011-9863-0

Flood, C. M., MacDonnell, V., Philpott, J., Thériault, S., \& Venkatapuram, S. (2020). Overview of COVID-19: Old and New Vulnerable. In C. M. Flood, V. MacDonnell, J. Philpott, S. Thériault, \& S. Venkatapuram (Eds.), Vulnerable (pp. 1-27).

Flook, L. (2011). Gender differences in adolescents' daily interpersonal events and wellbeing. Child development, 82(2), 454-461. Retrieved from https://onlinelibrary.wiley.com/doi/abs/10.1111/j.14678624.2010.01521.x. doi:doi:10.1111/j.1467-8624.2010.01521.x

Foundation, J. (2020). Children's World Report. Retrieved from https://isciweb.org/wpcontent/uploads/2020/07/Summary-Comparative-Report-2020.pdf

Foundation, V. (2017). Generation Z: global citizenship survey. Retrieved from London: https://www.varkeyfoundation.org/media/4487/global-young-people-report-single-pages-new.pdf 
Gao, J., Zheng, P., Yingnan, J., Chen, H., Mao, Y., Chen, S., ... Dai, J. (2020). Mental health problems and social media exposure during COVID-19 outbreak. PLoS One, 15(4). Retrieved from https://search.proquest.com/docview/2390642611?accountid=10910

Garrote, A., Sermier Dessemontet, R., \& Moser Opitz, E. (2017). Facilitating the social participation of pupils with special educational needs in mainstream schools: A review of school-based interventions. Educational Research Review, 20, 12-23. Retrieved from http://www.sciencedirect.com/science/article/pii/S1747938X16300604. doi:https://doi.org/10.1016/j.edurev.2016.11.001

Giannini, S. (2020, 25 March 2020). Three ways to plan for equity during the coronavirus school closures. Retrieved from https://gemreportunesco.wordpress.com/2020/03/25/three-ways-to-planfor-equity-during-the-coronavirus-school-closures/

Greco, S., Holmes, M., \& McKenzie, J. (2015). Friendship and Happiness from a Sociological Perspective. In M. Demir (Ed.), Friendship and Happiness Across the Life-Span and Cultures (pp. 19-32). Dordrecht: Springer Science+Business Media.

Hall, G., Laddu, D. R., Phillips, S. A., Lavie, C. J., \& Arena, R. (2020). A tale of two pandemics: How will COVID-19 and global trends in physical inactivity and sedentary behavior affect one another? Progress in Cardiovascular Diseases. doi:10.1016/j.pcad.2020.04.005

Indonesia, BBC. (2020, 21 April 2020). Virus corona: Di pesantren Magetan, 6.000 santri jalankan social distancing dan ganti nampan dengan piring setelah santri Malaysia terinfeksi Covid-19 [Coronavirus: 6,000 students in pesantren in Magetan do physical distancing and use individual plate after a student from Malaysia is infected]. BBC News Indonesia. Retrieved from https://www.bbc.com/indonesia/indonesia-52367041

Kapoor, N., Rahman, S., \& Kaur, T. (2018). Meaning of happiness: A qualitative inquiry among adolescents. Indian Journal of Positive Psychology, 9(1), 178-183. Retrieved from https://search.proquest.com/docview/2030131722?accountid=10910

Kebudayaan, K. P. d. (2020). Bantuan Kuota Data Internet 2020. Retrieved from https://kuotabelajar.kemdikbud.go.id/

Kemp, S. (2020, 18 February 2020). Digital 2020: Indonesia. Retrieved from https://datareportal.com/reports/digital-2020-indonesia

Keyes, C. L. M. (2006). Mental health in the CDS youth: Is America's youth flourishing? The American Journal of Orthopsychiatry, 76(3), 395-402. doi:10.1037/0002-9432.76.3.395

Koivumaa-Honkanen, H., Kaprio, J., Honkanen, R., Viinamäki, H., \& Koskenvuo, M. (2004). Life satisfaction and depression in a 15-year follow-up of healthy adults. Social Psychiatry and Psychiatric Epidemiology, 39(12), 994-999. Retrieved from https://doi.org/10.1007/s00127-004-0833-6.

Lewis, A. D., Huebner, E. S., Malone, P. S., \& Valois, R. F. (2011). Life satisfaction and student engagement in adolescents. Journal of Youth and Adolescence, 40(3), 249-262. Retrieved from https://search.proquest.com/docview/1037885912?accountid=10910

Lightsey, O. R. (1994). "Thinking positive" as a stress buffer: The role of positive automatic cognitions in depression and happiness. Journal of Counseling Psychology, 41(3), 325-334. doi:10.1037/0022-0167.41.3.325

Loades, M. E., Chatburn, E., Higson-Sweeney, N., Reynolds, S., Shafran, R., Brigden, A., ... Crawley, E. (2020). Rapid systematic review: The impact of social isolation and loneliness on the mental health of children and adolescents in the context of COVID-19. Journal of the American Academy of Child \& Adolescent Psychiatry, 1218-1239. 
Luthra, P., \& Mackenzie, S. (2020, 30 March 2020). 4 ways COVID-19 could change how we educate future generations. Retrieved from https://www.weforum.org/agenda/2020/03/4-ways-covid-19education-future-generations/

Lynch, S. (2015). Friendship and happiness from a philosophical perspective. In M. Demir (Ed.), Friendship and Happiness Across the Life-Span and Cultures (pp. 3-18). Dordrecht: Springer Science+Business Media.

Margaritis, I., Houdart, S., Ouadrhiri, Y. E., Bigard, X., Vuillemin, A., \& Duché, P. (2020). How to deal with COVID-19 epidemicrelated lockdown physical inactivity and sedentary increase in youth? Adaptation of Anses' benchmarks. Archives of Public Health, 78, 1-6. doi:10.1186/s13690-020-00432-z

Mathers, M. (2020, 4 May 2020). Coronavirus: How to keep children healthy, happy and learning during school closures. Independent. Retrieved from https://www.independent.co.uk/life-style/healthand-families/coronavirus-children-school-closed-healthy-happy-learning-a9412976.html

Mediana. (2020, 28 March 2020). Pondok Pesantren Mulai Pulangkan Para Santri [Islamic boarding school start to send their students home]. Kompas. Retrieved from https://kompas.id/baca/humaniora/dikbud/2020/03/28/pondok-pesantren-mulai-pulangkan-parasantri/

Mittal, V. A., Firth, J., \& Kimhy, D. (2020). Combating the dangers of sedentary activity on child and adolescent mental health during the time of COVID-19. Journal of the American Academy of Child \& Adolescent Psychiatry, 59, 1197-1198.

Moreno, J. M., \& Gortazar, L. (2020, 8 April 2020). Schools' readiness for digital learning in the eyes of principals. An analysis from PISA 2018 and its implications for the COVID19 (Coronavirus) crisis response. Retrieved from https://blogs.worldbank.org/education/schools-readiness-digital-learningeyes-principals-analysis-pisa-2018-and-its

Mulyana, C. (2020, 15 March 2020). Cegah Covid-19, Pendidikan Islam Diminta Ikuti Kebijakan. mediaindonesia.com.

Okazaki, K., Suzuki, K., Sakamoto, Y., \& Sasaki, K. (2015). Physical activity and sedentary behavior among children and adolescents living an area affected by the 2011 Great East Japan earthquake and tsunami for 3 years. Preventive Medicine Reports, 2, 720-724.

Orgilés, M., Morales, A., Delveccio, E., Mazzeschi, C., \& Espada, J. P. (2020). Immediate psychological effects of the COVID-19 quarantine in youth from Italy and Spain. PsyArXiv. Retrieved from https://psyarxiv.com/5bpfz/.

Ricci, F., Izzicupo, P., Moscucci, F., Sciomer, S., Maffei, S., Baldassarre, A. D., . . Gallina, S. (2020). Recommendations for physical inactivity and sedentary behavior during the coronavirus disease (COVID19) pandemic. Frontiers in Public Health, 8. doi:10.3389/fpubh.2020.00199

Rohmah, N. (2020, 27 March 2020). Dampak Covid-19 Memunculkan Monster Pendidikan di Rumah. Retrieved from https://www.timesindonesia.co.id/read/news/259829/dampak-covid19memunculkan-monster-pendidikan-di-rumah

Saldarriaga, L. M., Bukowski, W. M., \& Greco, C. (2015). Friendship and Happiness: A Bidirectional Dynamic Process. In M. Demir (Ed.), Friendship and Happiness Across the Life-Span and Cultures (pp. 5978). Dordrecht: Springer Science+Business Media.

Santoso, B. (2020, 25 March 2020). Ponpes Lirboyo Keluarkan Maklumat Khusus Terkait Corona, Ini Isinya [Pesantren Lirboyo anounces notice regarding corona]. SuaraJatim.id. Retrieved from https://jatim.suara.com/read/2020/03/25/063635/ponpes-lirboyo-keluarkan-maklumat-khususterkait-corona-ini-isinya?page=all 
Saveedra, J. (2020, 30 March 2020). Educational challenges and opportunities of the Coronavirus (COVID-19) pandemic. Retrieved from https://blogs.worldbank.org/education/educational-challengesand-opportunities-covid-19-pandemic

Seo, E. H., Kim, S.-G., Kim, S. H., Kim, J. H., Park, J. H., \& Yoon, H.-J. (2018). Life satisfaction and happiness associated with depressive symptoms among university students: a cross-sectional study in Korea. Annals of general psychiatry, 17, 52-52. Retrieved from https://pubmed.ncbi.nlm.nih.gov/30568720 https://www.ncbi.nlm.nih.gov/pmc/articles/PMC6297950/. doi:10.1186/s12991-018-0223-1

Sidik, F. M. (2020, 29 May 2020). Imbau Pemerintah Tak Buru-buru Buka Pesantren, Ini Saran Muhammadiyah [Muhammadiyah suggests the government not to open islamic boarding school in hurry]. detikNews. Retrieved from https://news.detik.com/berita/d-5032804/imbau-pemerintah-tak-buruburu-buka-pesantren-ini-saran-muhammadiyah

Smoyer, A. B., O'Brien, K., \& Rodriguez-Keyes, E. (2020). Lessons learned from COVID-19: Being known in online social work classrooms. International Social Work, 63 (5), 651 -654. doi:10.1177/0020872820940021

Steinberg, L. (2005). Cognitive and affective development in adolescence. Trends in Cognitive Sciences, 9, 69-74.

Tari, D. N. (2020, 16 March 2020). Tangkal Corona, Sekolah dan Pesantren di Riau Diliburkan hingga 30 Maret 2020 [Preventing coronavirus, schools and pesantren in Riau are closed until 30 March 2020]. Bisnis Sumatra. Retrieved from https://sumatra.bisnis.com/read/20200316/533/1213707/tangkalcorona-sekolah-dan-pesantren-di-riau-diliburkan-hingga-30-maret-2020

Thompson, T., Rodebaugh, Thomas L., Bessaha, Melissa L., \& Sabbath, Erika L. (2020). The association between social isolation and health: An analysis of parent-adolescent dyads from the family life, activity, sun, health, and eating study. Clinical Social Work Journal, 48, 18-24.

UNESCO. (2020a, 25 March 2020). Adverse consequences of school closures. Retrieved from https://en.unesco.org/covid19/educationresponse/consequences

UNESCO. (2020b, 6 March 2020). COVID-19 : 10 Recommendations to plan distance learning solutions. Retrieved from https://en.unesco.org/news/covid-19-10-recommendations-plan-distancelearning-solutions

UNESCO. (2020c, 8 April 2020). COVID-19 Educational Disruption and Response. Retrieved from https://en.unesco.org/covid19/educationresponse

UNESCO. (2020d). Distance learning solutions Retrieved from https://en.unesco.org/covid19/educationresponse/solutions

Wagner, K. D. (2020). New Findings About Children's Mental Health During COVID-19. Retrieved from https://www.psychiatrictimes.com/view/new-findings-children-mental-health-covid-19

Wang, G., Zhang, Y., Zhao, J., Zhang, J., \& Jiang, F. (2020). Mitigate the effects of home confinement on children during the COVID-19 outbreak. 395, 945-947. doi:10.1016/S0140-6736(20)30520-1

Whiteley, P., Clarke, H. D., \& Stewart, M. (2020, 3 July 2020). If health equals happiness, will Coronavirus make the world an unhappier place? The Conversation. Retrieved from https://theconversation.com/if-health-equals-happiness-will-coronavirus-make-the-world-anunhappier-place-141465

Wind, T. R., Rijkeboer, M., Andersson, G., \& Riper, H. (2020). The COVID-19 pandemic: The 'black swan' for mental health care and a turning point for e-health. Internet Interventions. doi:10.1016/j.invent.2020.100317 
Wootton, R. E., Davis, O. S. P., Mottershaw, A. L., Wang, R. A. H., \& Haworth, C. M. A. (2017). Genetic and environmental correlations between subjective wellbeing and experience of life events in adolescence. European Child \& Adolescent Psychiatry, 26(9), 1119-1127. Retrieved from https://doi.org/10.1007/s00787-017-0997-8. doi:10.1007/s00787-017-0997-8

Xiang, M., Zhang, Z., \& Kuwahara, K. (2020). Impact of COVID-19 pandemic on children and adolescents' lifestyle behavior larger than expected. Progress in Cardiovascular Diseases, 63, 531-532.

Yap, S. T., \& Baharudin, R. (2016). The Relationship Between Adolescents' Perceived Parental Involvement, Self-Efficacy Beliefs, and Subjective Wellbeing: A Multiple Mediator Model. Social Indicators Research, 126(1), 257-278. $\quad$ Retrieved from https://search.proquest.com/docview/1764077980?accountid=10910

Yeasmin, S., Banik, R., Hossain, S., Hossain, M. N., Mahumud, R., Salma, N., \& Hossain, M. M. (2020). Impact of COVID-19 pandemic on the mental health of children in Bangladesh: A cross-sectional study. Children and Youth Services Review, 117, 105277. Retrieved from https://www.sciencedirect.com/science/article/pii/S0190740920309488. doi:https://doi.org/10.1016/j.childyouth.2020.105277

Zhou, S.-J., Zhang, L.-G., Wang, L.-L., Guo, Z.-C., Wang, J.-Q., Chen, J.-C., ... Chen, J.-X. (2020). Prevalence and socio-demographic correlates of psychological health problems in Chinese adolescents during the outbreak of COVID-19. European Child \& Adolescent Psychiatry, 29(6), 749-758. Retrieved from https://doi.org/10.1007/s00787-020-01541-4. 